\title{
Spectrophotometric Indirect Determination of Captopril through Redox Reaction with n-bromosuccinimide and RB dye in Pharmaceutical Products
}

\author{
Dashne M. Kokhasmail ${ }^{1}$, Tara F. Tahir ${ }^{2}$ and Kurdistan F. Azeez ${ }^{1}$ \\ ${ }^{1}$ Department of Chemistry, Faculty of Science and Health, Koya University, \\ Koya KOY45, Kurdistan Region - F.R. Iraq \\ ${ }^{2}$ Department of Medical Microbiology, Faculty of Science and Health, Koya University, \\ Koya KOY45, Kurdistan Region - F.R. Iraq
}

\begin{abstract}
A simple, accurate, and sensitive method for the spectrophotometric determination of captopril in bulk and dosage forms is reported. The method is based on the bromination of captopril with excess solution of $n$-bromosuccinimide (NBS) in $\mathrm{HCl}$ acid medium. The excess NBS is pursued by the assessment of the residual NBS based on its ability to bleach the rhodamine $B$ dye and measuring the absorbance at $555 \mathrm{~nm}$. The amount of NBS reacted coincides to the drug content. The different experimental parameters influencing the development and stability of the color are precisely studied and optimized. Beer's law is valid within a concentration range of $0.3-1.0 \mu \mathrm{g} / \mathrm{mL}$ with a correlation coefficient $R^{2}=0.991$. The limit of detection $0.169 \mu \mathrm{g} / \mathrm{mL}$ is attained and relative standard deviation values for five replicated measurements of $0.3,0.7$, and $1.0 \mu \mathrm{g} / \mathrm{mL}$ captopril were between $0.53 \%$ and $\mathbf{2 . 0 3 \%}$. No interference is detected from prevalent additives found in pharmaceutical preparations. The proposed method is profitably put on to the determination of captopril in the tablet formulations with mean recoveries $98.91-101.27 \%$ and the results were statistically confronted with those of a reference method by applying Student's t-and F-test.
\end{abstract}

Index Terms-Captopril, Indirect determination, n-bromosuccinimide, Rhodamine B, Spectrophotometer.

\section{INTRODUCTION}

Hypertension takes place with two-fold the recurrence in the diabetic community in comparison with the nondiabetic community, and more than 50\% of patients with type 2 diabetes mellitus develop into hypertensive (Parving, et al., 1983). Besides, enduring a large risk cause

\section{ARO-The Scientific Journal of Koya University}

Vol. VIII, No.2 (2020), Article ID: ARO.10662, 7 pages

DOI: $10.14500 /$ aro. 10662

Received 12 April 2020; Accepted 27 July 2020

Regular research paper: Published 01 September 2020

Corresponding author's e-mail: tara.fuad@koyauniversity.org

Copyright (C) 2020 Dashne M. Kokhasmail, Tara F. Tahir, Kurdistan

F. Azeez. This is an open-access article distributed under the Creative Commons Attribution License. for atherosclerosis in large blood vessels, hypertension in diabetes contributes to mini-vessel disease and is a danger cause for diabetic nephropathy and probably for diabetic retinopathy. Investigations have presented that angiotensin-converting enzyme (ACE) inhibitors can sluggish the development of diabetic nephropathy in patients with type 1 or type 2 diabetes with microalbuminuria or macroalbuminuria (Phillip and Hall, 2006).

A main thing whither toward preserve the kidney from the complexity of diabetes is to manage elevated blood pressure destructively, despite the antihypertensive drug types utilized. Literature stated that patients with type 1 diabetes and antihypertensive drugs such as diuretics, beta-blockers, and hydralazine were taken, demonstrating that decreasing blood pressure diminishes proteinuria and sluggish the dismiss of renal work (Lewis, et al., 1993). A predominance of clue records that ACE inhibitors preserve the kidney more than undertake other blood pressure suppressing medications, apparently because ACE inhibitors particularly reduce the intrarenal pressure.

Patients with type 1 diabetes, albuminuria, and mildly impaired creatinine clearance were exposed to a milestone study. The ACE inhibitor captopril was diminished the risk of a decline in renal function more effectively than did other antihypertensive regimens (Lewis, et al., 1993). It has been found that captopril is powerful in lowering blood pressure and also lowering the risk of macrovascular end points. It was confirmed that captopril does not develop any important differences in the blood levels of ionized calcium or phosphorous ions and that it does not modify the serum levels of parathyroid hormone (PTH) and metabolites of Vitamin D (Florentin, et al., 2004).

Captopril (1-[(2S)-2-methyl-3-sulfanylpropanoyl]-Lproline) is an inhibitor of ACE, acting directly on the adrenal gland to activate the release of aldosterone (Fig. 1). It inhibits elevated blood pressure by preventing the enzymatic alteration of angiotensin I to angiotensin II. It is a white crystalline powder $\left(\mathrm{C}_{9} \mathrm{H}_{15} \mathrm{NO}_{3} \mathrm{~S}\right.$, molar mass $\left.217.29 \mathrm{~g} / \mathrm{mol}\right)$ 


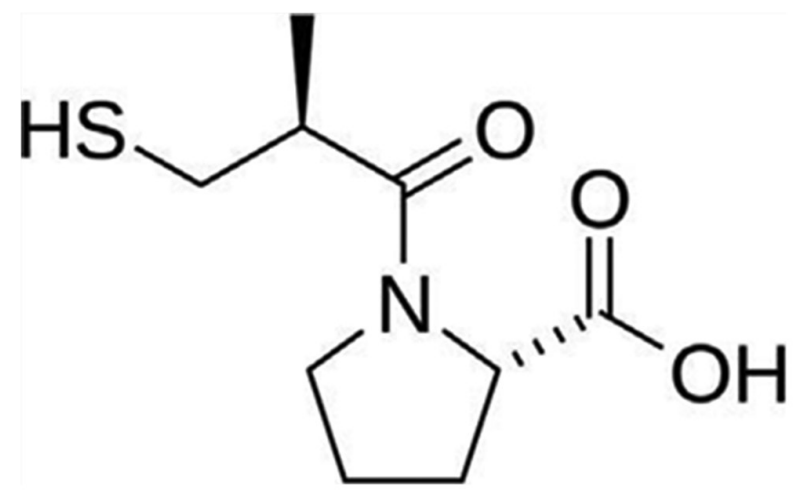

Fig. 1. Chemical structure of captopril.

having an essence sulfide-like odor and a melting point between 105 and $108^{\circ} \mathrm{C}$. Captopril is plainly soluble in water or diluted solutions of alkali hydroxides, in alcohols, in methylene chloride, or in chloroform (Milan, et al., 2015).

Many methods were available for the determination of captopril in various samples including pharmaceutical products. The first approaches to captopril determination in biological matrix were made by liquid chromatography (LC) and mass spectrometry (Salem, et al., 2005, Vancea, et al., 2009).

Captopril is determined in blood, plasma, and urine using an investigate method of high-performance LC (HPLC). Nevertheless, determination methods of low concentration levels of captopril based on oxidation reaction are pursued three different oversights: Apply of extra sensitive detection method as an alternative to ultraviolet (UV) method such as electrochemical method without any derivatization of the analyte; detection of a derivatized product of captopril that is identified before or after chromatographic separation using the UV or fluorescent method; and utilize of preconcentration techniques such as liquid-liquid extraction and multicolumn switching setup (Florentin, et al., 2004).

Despite the fact that captopril is non-toxic, but appropriate caution must be taken because it can cause hypotension when overdosed. This result is only expected following ingestion of quantities $>450 \mathrm{mg} /$ day. Taking medicines of captopril level above the accepted value can be harmful to the patient (Jia, et al., 2001). Accordingly, there is a sustaining demand for the development of new analytical procedures for the determination of captopril in pharmaceutical products (Lima, et al., 2016).

HPLC is recognized as a favored analytical technique for identification and quantification of most pharmaceutical products including captopril (Iqbal, et al., 2015). Disregarding that the advantage of HPLC as it is a well-built technology in the pharmaceutical field, offering sensitivity and specificity, it has defects that include high operation costs, the demand for large amounts of samples and solvents, and the formation of hazardous wastes such as organic solvents that are costly to relinquish and can have significant environmental impacts (Safila, et al., 2013).

In the published works, different methods were reported for the determination of captopril which include atomic absorption spectrometry, spectrophotometry, chemiluminescence, LC, amperometry, electrophoresis, and HPLC techniques (El-reis, et al., 2000; El-Shanawany, et al., 2014; Zhaofu, et al.,
2017; Fu, et al., 2017, Shafi, et al., 2015; Marcolino-Junior, et al., 2009; Tomas, et al., 2006; Iqbal, et al., 2015, Zhang, et al., 2020).

The use of spectrophotometry provides a simple and inexpensive technique for the determination of drugs in pharmaceutical products. Sensitivity is another important characteristic of molecular absorption technique. Besides, the large linear concentration ranges make the method interesting and versatile for routine analysis of drugs in quality control laboratories (Rao, et al., 2012). Most of the reported methods were based on the redox reaction of captopril with an excess of an oxidizing agent (El-Didamony and Erfan, 2010; Skowron and Ciesielski, 2011).

The aim of the present work was, therefore, to use a convenient, low cost but sensitive analytical method as spectrophotometer for quantification of captopril in pharmaceuticals based on redox reaction with $\mathrm{n}$-bromosuccinimide (NBS) and rhodamine $\mathrm{B}$ dye $(\mathrm{RB})$. The results were compared with the recommended method described in the literature.

\section{EXPERIMENTAL}

\section{A. Apparatus}

Molecular absorption spectra were measured using UV1000 CECIL 1021 spectrophotometer, UK, with a glass cell of $1.0 \mathrm{~cm}$ optimal path length. LW Scientific Digital Water Bath, US, was used to control the temperature of the solution during the studies. The studies were accomplished using HPLC system of Agilent 1100 controlled by ChemStation Data System. A G 1311A quaternary pump and UV detector (VWD-G1314 A) were supplied with the system. A reverse phase C18 column (Kromasil 100-5-Phenyl ${ }^{\circledR}, 300 \mathrm{~mm} \times 4.6 \mathrm{~mm}, 5 \mu \mathrm{m}$ ) was handling at $25^{\circ} \mathrm{C}$ and the mobile phase of $0.1 \% \mathrm{v} / \mathrm{v}$ trifluoroacetic acid and acetonitrile at ratio $(80: 20 \mathrm{v} / \mathrm{v})$ was provided during the investigation. The flow rate of $1.5 \mathrm{~mL} / \mathrm{min}$ elute was advised at wavelength $290 \mathrm{~nm}$.

\section{B. Material and Reagent}

Captopril was collected from Awamedica Pharmaceutical Company (Kurdistan region, Iraq), used as received, the purity of which was $99.9 \%$. A solution of $100 \mu \mathrm{g} / \mathrm{mL}$ of NBS (from Fluka) was prepared by dissolving $0.1 \mathrm{~g}$ of NBS $\left(\mathrm{C}_{4} \mathrm{H}_{4} \mathrm{BrNO}_{2}\right)$ in small amount of warm water, then diluted to $1000 \mathrm{~mL}$ with distilled water, and kept in $5^{\circ} \mathrm{C}$ refrigerator until further usage. A dye solution of $100 \mu \mathrm{g} / \mathrm{mL}$ of RB (from RIEDEL-DEHAEN) was prepared by dissolving $0.1 \mathrm{~g}$ of RB in distilled water and diluted to $1000 \mathrm{~mL}$ with distilled water (the solution is stable for at least 2 weeks). Hydrochloric acid, sulfuric acid, nitric acid, and acetic acid (from Scharlau) of $1 \mathrm{~mol} / \mathrm{L}$ solution were prepared, individually. Interfering solutions of $500 \mu \mathrm{g} / \mathrm{mL}$ of fructose (from BDH), glucose (SCP), lactose (BDH), starch (from Difco), and sucrose (from Difco) were prepared individually by dissolving $0.1 \mathrm{~g}$ of solid compound in $100 \mathrm{ml}$ distilled water.

\section{Preparation of Standard and Sample Solution}

A stock solution of standard captopril $1000 \mu \mathrm{g} / \mathrm{mL}$ was prepared by dissolving $0.1 \mathrm{~g}$ of standard captopril powder in 
$20 \mathrm{~mL}$ distilled water with stirring carefully, then the volume was completed to $100 \mathrm{~mL}$ volumetric flask with the same solvent and kept in $5^{\circ} \mathrm{C}$ refrigerator to remain stable for 28 days (Pereira and Tam, 1992). Working standard solutions were prepared daily by proper dilution of the stock standard solution with the same solvent.

All pharmaceutical products of captopril in the local medical store are containing $25 \mathrm{mg}$ and two different companies were used for the determination (captopril Awa, Erbil, Iraq, and Rilcapton, Medochemie-Cyprus). Ten tablets of captopril were weighed and crushed for each pharmaceutical company, and the sample powder of the two companies was accurately weighed individually and placed in a $50.0 \mathrm{~mL}$ beaker, then dissolved in $30.0 \mathrm{~mL}$ of distilled water. The solution was stirred for $10 \mathrm{~min}$ to increase solubility. Insoluble excipient was removed by filtration using Whatman No. 41 membrane filter paper. The filtered solution was diluted to $100 \mathrm{~mL}$ in a volumetric flask with the same solvent.

\section{Analytical Procedure}

In $25.0 \mathrm{~mL}$ volumetric flask, $2.5 \mathrm{~mL}$ of NBS $(100 \mu \mathrm{g} / \mathrm{mL})$, $0.8 \mathrm{~mL}$ of $\mathrm{HCl}(1 \mathrm{~mol} / \mathrm{L})$, and adequate captopril standard or sample $(0.3-1.0 \mu \mathrm{g} / \mathrm{mL})$ of $100 \mu \mathrm{g} / \mathrm{mL}$ solution were added. This mixture was shacked thoroughly and left to stand for $10 \mathrm{~min}$ at $25 \pm 2^{\circ} \mathrm{C}$. Finally, $2.5 \mathrm{~mL}$ of $\mathrm{RB}(100 \mu \mathrm{g} / \mathrm{mL})$ was added and directly diluted to the mark with distilled water. The absorbance was measured against reagent blank prepared in similar conditions without captopril at $555 \mathrm{~nm}$.

\section{RESUltS AND DiscusSION}

Captopril is acting as a reducing agent due to the presence of thiol group (- $\mathrm{SH})$ in its structure and the literature explains that captopril in aqueous solution undergoes oxidative degradation at its thiol function to yield captopril-disulfide (Chenl, et al., 1995). In this work, the reaction involves two steps (Fig. 2):

(i) Oxidation of the drug (captopril) by excess of NBS reagent, generated in sedentary by the action of $\mathrm{HCl}$ acid solution on captopril-disulfide

(ii) Determination of unreacted oxidant NBS by bleaching the color of RB dye in acidic medium (Abdel-Hady, 2013).

The absorption spectrum of the yielded bleaching $2.5 \mathrm{~mL}$ of $(100 \mu \mathrm{g} / \mathrm{mL}) \mathrm{RB}$ demonstrated the maximum absorbance at $555 \mathrm{~nm}$ against the blank solution after $10 \mathrm{~min}$ (Fig. 3a). The absorbance of individual $0.7 \mu \mathrm{g} / \mathrm{mL}$ captopril showed dropping at the same wavelength (Fig. 3b), whereas no significant absorbance was recorded for the blank reagent of NBS and RB dye (Fig. 3c).

\section{A. Optimum of Experimental Conditions}

The reaction conditions along with the different experimental parameters influencing the color development and stability of the dye were laboriously examined and optimized for the quantitative determination of captopril in bulk and the tablet dosage forms.

\section{Selection of type and acid concentration}

The reaction of $0.7 \mu \mathrm{g} / \mathrm{mL}$ captopril with $2.5 \mathrm{~mL}$ of $(100 \mu \mathrm{g} / \mathrm{mL})$ solution of each of NBS and RB dye was tested in $1 \mathrm{~mol} / \mathrm{L}$ of $\mathrm{HCl}, \mathrm{HNO}_{3}, \mathrm{H}_{2} \mathrm{SO}_{4}$, and $\mathrm{CH}_{3} \mathrm{COOH}$ solutions, individually. The results demonstrated that the reaction is suitable in hydrochloric acid medium (Fig. 4a). A $1 \mathrm{~mol} / \mathrm{L}$ $\mathrm{HCl}$ solution was found to be sufficient for the oxidation of captopril as well as the bleaching of RB dye. The variation in $\mathrm{HCl}$ volumes indicated that highest absorbance was observed with $0.8 \mathrm{~mL}$ of $1 \mathrm{~mol} / \mathrm{L} \mathrm{HCl}$, subsequent studies were performed with this volume and concentration of $\mathrm{HCl}$ (Fig. 4b).

\section{Sequence of addition}

The sequence of addition of $2.5 \mathrm{~mL}(100 \mu \mathrm{g} / \mathrm{mL}) \mathrm{NBS}$ oxidant, drug solution, $2.5 \mathrm{~mL}(100 \mu \mathrm{g} / \mathrm{mL}) \mathrm{RB}$ dye, and $0.8 \mathrm{~mL}(1 \mathrm{~mol} / \mathrm{L}) \mathrm{HCl}$ was studied through bleaching the color of RB dye and measuring its absorbance at $555 \mathrm{~nm}$ (Fig. 5). Best absorbance was accomplished when the sequence was in the order; drug, $\mathrm{NBS}, \mathrm{HCl}$, and then $\mathrm{RB}$. This study is compatible and confirmed with the mechanism of reaction in Fig. 2.

\section{Reagent and dye concentrations}

Elementary experiments were achieved to fix the upper limits of RB dye that could be determined spectrophotometrically in acid medium and this was found to be $2.5 \mathrm{~mL}$ of $100 \mu \mathrm{g} / \mathrm{mL}$ of $\mathrm{RB}$. This concentration gave stable and high intensity that was the reasonable concentration for this procedure.

A high concentration of oxidant NBS $>100 \mu \mathrm{g} / \mathrm{mL}$ was found to destroy the color of RB dye. Under the experimental conditions, different volumes between 0.5 and $3.0 \mathrm{~mL}$ of

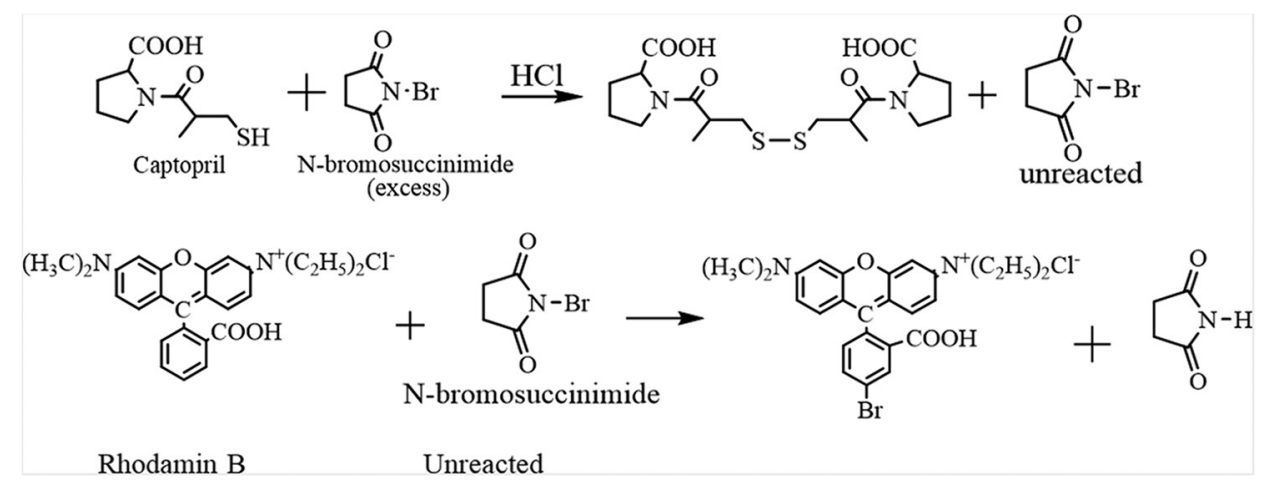

Fig. 2. Mechanism of oxidation of captopril by excess NBS and the latest reaction with RB dye. 
$100 \mu \mathrm{g} / \mathrm{mL}$ NBS were examined (Table I). Therefore, $2.5 \mathrm{~mL}$ of NBS was adopted in the recommended procedure.

\section{Effect of temperature and heating time}

The redox reaction of $0.7 \mu \mathrm{g} / \mathrm{mL}$ captopril, $2.5 \mathrm{ml}$ $(100 \mu \mathrm{g} / \mathrm{mL})$ NBS solution, and $2.5 \mathrm{~mL}(100 \mu \mathrm{g} / \mathrm{mL}) \mathrm{RB}$ dye in $0.8 \mathrm{~mL}(1 \mathrm{~mol} / \mathrm{L})$ of $\mathrm{HCl}$ acidic medium was examined at various temperatures and heating times through measuring the absorbance (Table II).

TABLE I

AMOUNT OF OXIDANT NBS SOLUTION FOR BLEACHING COLOR OF RB DYE VERSUS ABSORBANCE

\begin{tabular}{lc}
\hline \hline Volume of NBS $(\mathrm{mL})$ & Absorbance \\
\hline 0.5 & 0.982 \\
1.0 & 0.730 \\
1.5 & 0.337 \\
2.0 & 0.183 \\
2.5 & 0.095 \\
3.0 & 0.005 \\
\hline \hline
\end{tabular}

TABLE II

EFFECT OF TEMPERATURE AND HEATING TIME ON THE ABSORBANCE OF RB DYE

\begin{tabular}{lcccccc}
\hline \hline Temperature ${ }^{\circ} \mathrm{C}$ & \multicolumn{6}{c}{ Absorbance } \\
\cline { 2 - 7 } & $10 \mathrm{~min}$ & $20 \mathrm{~min}$ & $30 \mathrm{~min}$ & $40 \mathrm{~min}$ & $50 \mathrm{~min}$ & $60 \mathrm{~min}$ \\
\hline 5 & 0.371 & 0.372 & 0.373 & 0.372 & 0.375 & 0.377 \\
10 & 0.449 & 0.447 & 0.445 & 0.445 & 0.447 & 0.449 \\
25 & 0.587 & 0.587 & 0.584 & 0.588 & 0.586 & 0.585 \\
50 & 0.457 & 0.459 & 0.453 & 0.451 & 0.450 & 0.449 \\
\hline \hline
\end{tabular}

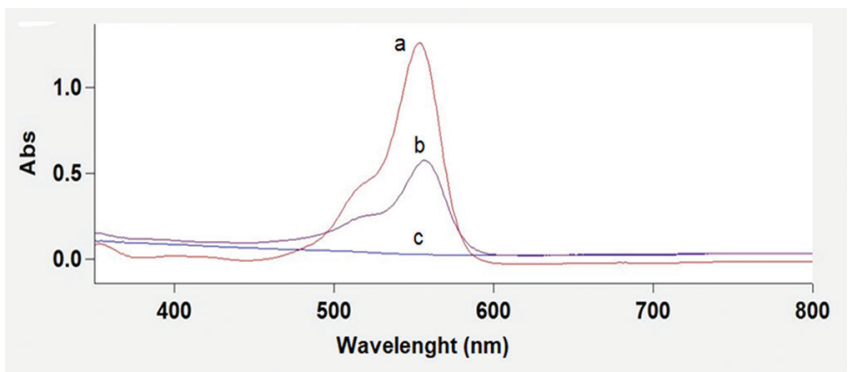

Fig. 3. Absorption spectra of (a) $2.5 \mathrm{~mL}$ of $(100 \mu \mathrm{g} / \mathrm{mL})$ rhodamine $\mathrm{B}$, (b) $0.7 \mu \mathrm{g} / \mathrm{mL}$ captopril, $2.5 \mathrm{~mL}(100 \mu \mathrm{g} / \mathrm{mL})$ of NSB and RB dye (c) blank reagent of $2.5 \mathrm{~mL}(100 \mu \mathrm{g} / \mathrm{mL})$ of NSB and $\mathrm{RB}$ solution against distilled water.
As a general rule, increasing the temperature $\left(5-25^{\circ} \mathrm{C}\right)$ will increase the reaction rate (for exothermic and endothermic) reactions simply because it means more energy available in the system. However, for the reversible exothermic reaction, there is a range of temperatures where this might not be true (Leenson, 1999). The absorbance was decreased as the temperature rose to $50^{\circ} \mathrm{C}$. The results obtained in Table II may be understood in terms of increased quantum yield of the RB dye as the temperature is reduced (Ali, et al., 1991). A $25^{\circ} \mathrm{C}$ was then applied for further investigation.

Reaction time and stability of dye color

Time is a denoting factor on completing the redox reaction of $0.7 \mu \mathrm{g} / \mathrm{mL}$ captopril with $2.5 \mathrm{~mL}(100 \mu \mathrm{g} / \mathrm{mL})$ NBS solution in $0.8 \mathrm{~mL}(1 \mathrm{~mol} / \mathrm{L})$ of $\mathrm{HCl}$ acidic medium and bleaching of $2.5 \mathrm{~mL}(100 \mu \mathrm{g} / \mathrm{mL}) \mathrm{RB}$ dye. The maximum absorbance was attained after $10 \mathrm{~min}$ at $25 \pm 2{ }^{\circ} \mathrm{C}$ (Fig. 6). The color intensity of RB dye was stable after $25 \mathrm{~min}$ for at least $24 \mathrm{~h}$ at room temperature.

\section{Interference studies}

The effects of common excipients added in pharmaceutical preparations in the form of tablets and capsules were tested for their possible interferences in the assessment of captopril under optimum conditions (El-Didamony and Erfan, 2010). The excipient solutions $(500 \mu \mathrm{g} / \mathrm{mL})$ of lactose, fructose, glucose, starch, and sucrose were mixed with $0.7 \mu \mathrm{g} / \mathrm{mL}$ pure captopril in the final volume of $25 \mathrm{~mL}$, individually. The spectra obtained were compared with the spectrum of $0.7 \mu \mathrm{g} /$ $\mathrm{mL}$ captopril standard solution. A level of interference was considered to be acceptable when the error is not higher than $\pm 5 \%$. No significant levels of interferences were observed in the determination of captopril in the presence of the common excipients (Table III).

\section{B. Analytical Figures of Merit}

Determination of captopril was investigated under optimum experimental conditions, when the relative standard deviation (RSD\%) was $2.33 \%$ as obtained from five replicated measurements of three different concentrations of captopril. In agreement with IUPAC guidelines of the validation of analytical method, the limit of detection value $(\mathrm{LOD})=3.3$ $\mathrm{SD} / \mathrm{P}$ was adopted, in which SD is the standard deviation of
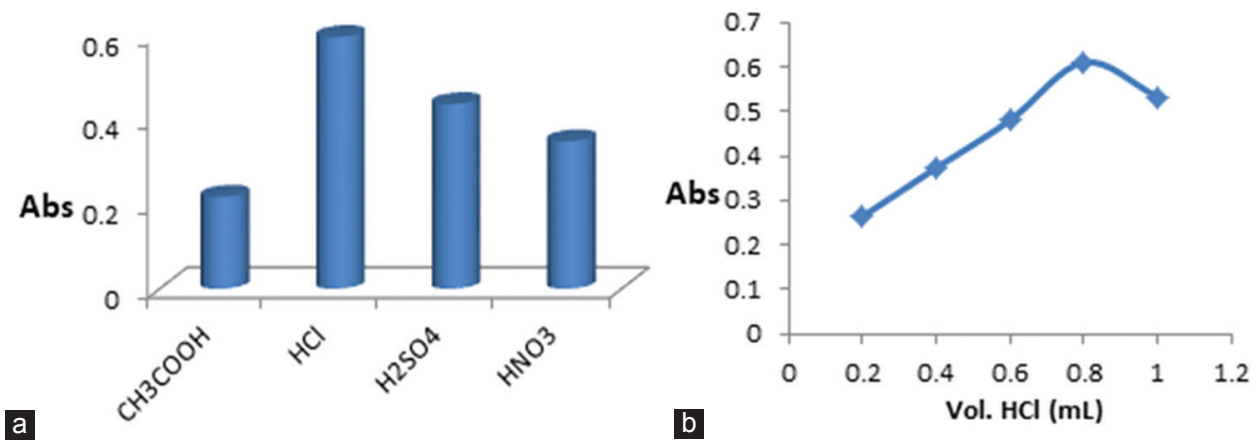

Fig. 4. (a) Absorbance vs. solutions that contain $0.7 \mu \mathrm{g} / \mathrm{mL}$ captopril, $2.5 \mathrm{~mL}$ of $(100 \mu \mathrm{g} / \mathrm{mL})$ solution of each of NBS and RB dye with $1 \mathrm{~mol} / \mathrm{L}$ of $\mathrm{CH} 3 \mathrm{COOH}, \mathrm{HCl}, \mathrm{H} 2 \mathrm{SO} 4$ and $\mathrm{HNO}$, individually; (b) Absorbance vs. solutions that contain $0.7 \mu \mathrm{g} / \mathrm{mL}$ captopril, $2.5 \mathrm{~mL}$ of (100 $\mu \mathrm{g} / \mathrm{mL}$ ) solution of each of NBS and RB dye with different volumes between $(0.2-1.0 \mathrm{~mL})$ of $1 \mathrm{~mol} / \mathrm{L} \mathrm{HCl}$ solution. 
five reagent blank measurements and $\mathrm{P}$ is the gradient of the calibration curve (Topic Q2 (R1): Validation of Analytical Procedures: Text and Methodology, International Conference on Harmonization (ICH), 2005, Ana, et al., 2014, Tahir, et al., 2019). The linear range was $0.3-1.0 \mu \mathrm{g} / \mathrm{mL}$ with correlation coefficient $\mathrm{R}^{2}=0.991$ and molar absorptivity of $2333 \mathrm{~L} / \mathrm{mol} / \mathrm{cm}$ (Fig. 7). The LOD and limit of quantification were $0.169 \mu \mathrm{g} / \mathrm{mL}$ and $0.304 \mu \mathrm{g} / \mathrm{mL}$, respectively. The regression equation of standard solutions was $\mathrm{Y}=1.0665 \mathrm{x}$ 0.1766 in which $\mathrm{x}$ is in $\mu \mathrm{g} / \mathrm{mL}$.

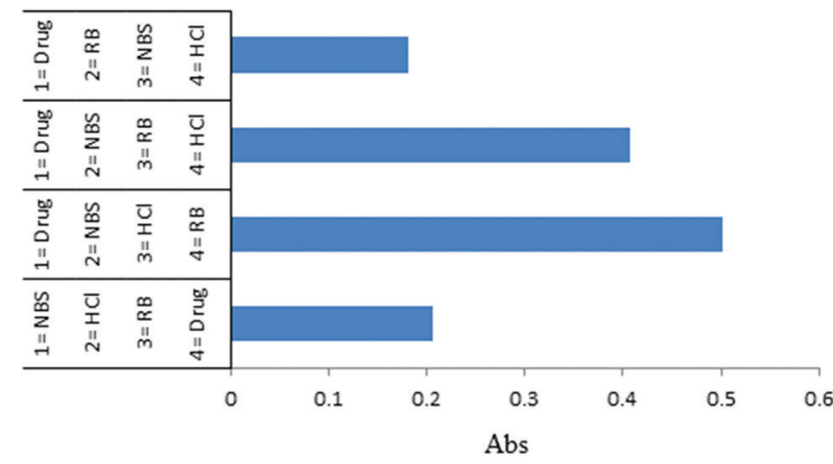

Fig. 5. Absorbance of different sequence of mixing captopril, $2.5 \mathrm{~mL}$ $(100 \mu \mathrm{g} / \mathrm{mL}) \mathrm{NBS}, 2.5 \mathrm{~mL}(100 \mu \mathrm{g} / \mathrm{mL}) \mathrm{RB}$ and $0.8 \mathrm{~mL}(1 \mathrm{~mol} / \mathrm{L}) \mathrm{HCl}$ solution.

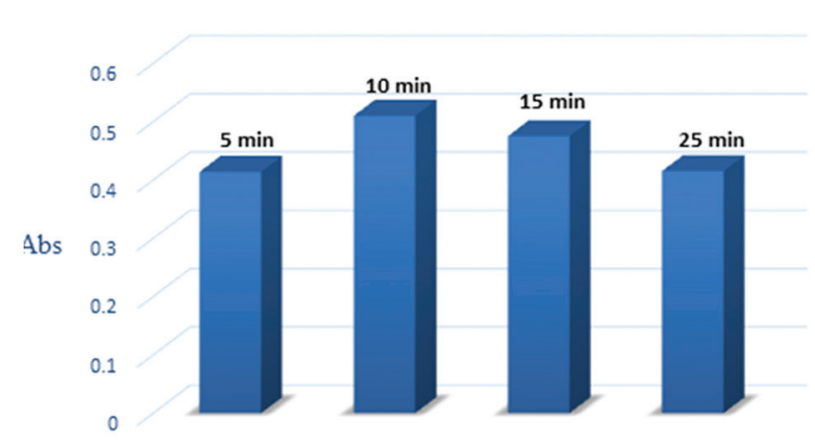

Fig. 6. Absorbance of $0.7 \mu \mathrm{g} / \mathrm{mL}$ captopril, $2.5 \mathrm{~mL}(100 \mu \mathrm{g} / \mathrm{mL}) \mathrm{NBS}$ and $2.5 \mathrm{~mL}(100 \mu \mathrm{g} / \mathrm{mL}) \mathrm{RB}$ solution in $0.8 \mathrm{~mL}(1 \mathrm{~mol} / \mathrm{L})$ of $\mathrm{HCl}$ acidic medium at different reaction times.
The accuracy and precision of the proposed procedure was provided by measuring the absorbance of RB dye after bleaching through excess amount of oxidant NBS that was remained after oxidation of three different concentrations of standard captopril $(0.3,0.7$, and $1.0 \mu \mathrm{g} / \mathrm{mL})$, individually in five replicate measurements (Table IV). The values of RSD $\%$ and $\mathrm{E} \%$ were between $0.53 \%-2.03 \%$ and $-1.42 \%-2.00 \%$, respectively, indicating that the proposed procedure is valid and applicative.

\section{Application and Comparison}

The proposed procedure was successfully bestowed for the determination of captopril in pharmaceutical tables. The ingredients in the pharmaceutical tablets did not interfere in the quantification of captopril. The applicability of the proposed procedure for the analysis of captopril in pharmaceutical formulations was examined by investigating two pharmaceutical tablets and the results are shown in Table $\mathrm{V}$ which were compared to the standard captopril assay using HPLC method. HPLC has the capability to detach and determine compounds that are exist in any sample that can

TABLE III

INTERFERENCE STUDIES OF CAPTOPRIL QUANTIFICATION TOWARD SOME COMMON EXCIPIENTS PRESENTED IN THE PHARMACEUTICAL PRODUCTS

\begin{tabular}{lcc}
\hline \hline Coexisting materials & Allowance concentrations $(\mu \mathrm{g} / \mathrm{mL})$ & $\mathrm{E} \% *$ \\
\hline Lactose & 500 & -1.90 \\
Fructose & 500 & 2.60 \\
Glucose & 500 & -2.20 \\
Starch & 500 & 2.30 \\
Sucrose & 500 & 2.60 \\
\hline \hline
\end{tabular}

* Average of three determinations

TABLE IV

ACCURACY AND PRECISION DATA FOR THE PROPOSED SPECTROPHOTOMETRIC INDIRECT DETERMINATION OF CAPTOPRIL

\begin{tabular}{lcccc}
\hline \hline $\begin{array}{l}\text { Contained amount } \\
(\mu \mathrm{g} / \mathrm{mL})\end{array}$ & $\begin{array}{c}\text { Found by proposed method } \\
(\mu \mathrm{g} / \mathrm{mL})\end{array}$ & SD & RSD\% & E\%* \\
\hline 0.3 & 0.305 & 0.002 & 2.030 & 1.66 \\
0.7 & 0.690 & 0.005 & 0.920 & -1.42 \\
1.0 & 1.020 & 0.005 & 0.530 & 2.00 \\
\hline \hline
\end{tabular}

*Average of five determinations

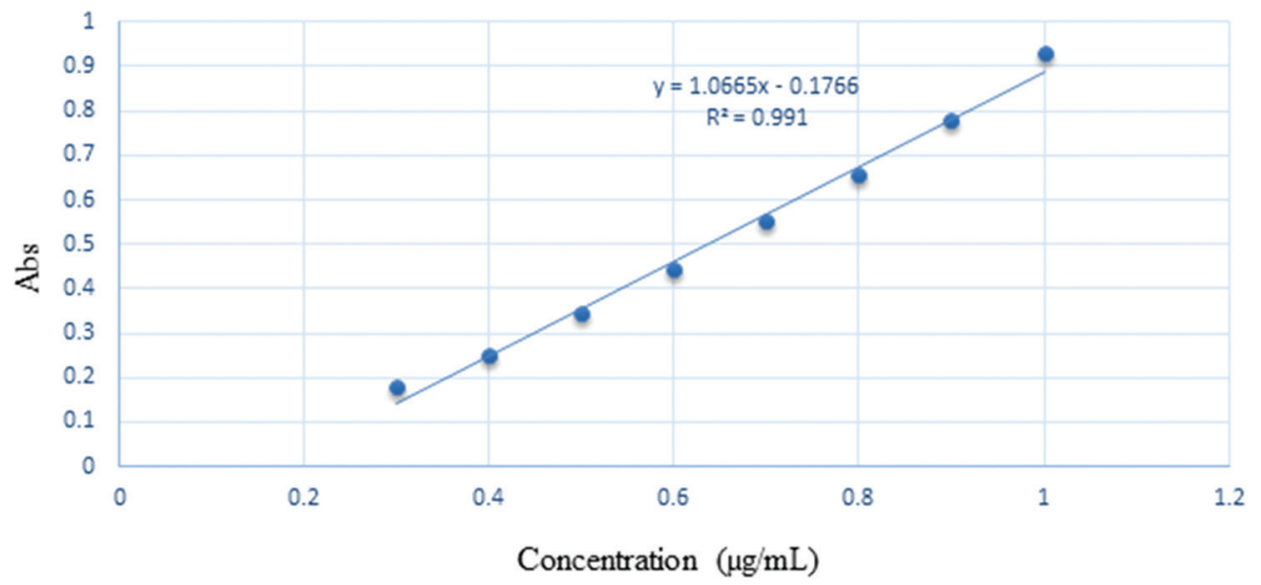

Fig. 7. Calibration curve of spectrophotometric indirect quantitation of captopril via oxidant NBS and RB dye in acidic medium under optimum condition. 
TABLE V

ANALYSIS OF CAPTOPRIL IN PHARMACEUTICAL FORMULATIONS USING THE PROPOSED METHOD AND STANDARD HPLC METHOD

\begin{tabular}{|c|c|c|c|c|c|c|}
\hline $\begin{array}{l}\text { Pharmaceutical } \\
\text { tablets }\end{array}$ & $\begin{array}{l}\text { Observed values } \\
(\mathrm{mg})\end{array}$ & $\begin{array}{l}\text { Values from proposed } \\
\text { procedure }\end{array}$ & $\begin{array}{l}\text { Values from } \\
\text { HPLC }\end{array}$ & $\begin{array}{c}\text { Recovery } \\
\%\end{array}$ & E \%* & $\mathrm{t}$ and $\mathrm{F}$ values** \\
\hline Captopril awa & 25 & $25.34 \pm 1.13$ & $25.02 \pm 0.14$ & 101.27 & 1.27 & $\mathrm{t}=1.36, \mathrm{~F}=1.78$ \\
\hline Rilcapton & 25 & $24.71 \pm 0.17$ & $24.98 \pm 0.08$ & 98.91 & -1.08 & $\mathrm{t}=1.02, \mathrm{~F}=1.98$ \\
\hline
\end{tabular}

*Average of five determinations, **Theoretical calculation of $\mathrm{t}$ and $\mathrm{F}$ at $95 \%$ confidence level $(\mathrm{n}=5)$ was 2.78 and 6.39 , respectively, ***The values \pm are the standard deviation of the five replication of each sample

TABLE VI

COMPARISON OF DETERMINATION OF CAPTOPRIL USING DIFFERENT REDOX REACTIONS THROUGH SPECTROPHOTOMETRIC TECHNIQUE AND THE PROPOSED METHOD

\begin{tabular}{llcc}
\hline \hline Method based on & Ref. & LR (mol/L) & LOD (mol/L) \\
\hline $\begin{array}{l}\text { Reduction of } \\
\text { ammonium molybdate }\end{array}$ & Ribeiro, et al., & $4.60 \times 10^{-4}-1.84 \times 10^{-3}$ & $7.31 \times 10^{-6}$ \\
$\begin{array}{l}\text { Reduction of } \\
\text { potassium dichromate }\end{array}$ & $\begin{array}{l}\text { Moldovan, } \\
\text { et al., 2012 }\end{array}$ & $3.68 \times 10^{-7}-1.61 \times 10^{-5}$ & $1.10 \times 10^{-7}$ \\
$\begin{array}{l}\text { Reaction of } \\
\begin{array}{l}\text { O-phthalaldehyde } \\
\text { Proposed work }\end{array}\end{array}$ & $\begin{array}{l}\text { El-Shanawany, } \\
\text { et al., 2014 }\end{array}$ & $9.20 \times 10^{-6}-1.15 \times 10^{-5}$ & - \\
\hline \hline
\end{tabular}

LR: Linear range, LOD: Limit of detection

be dissolved in a liquid in trace concentrations as low as parts per trillion (Iqbal, et al., 2015).

The performance of the proposed procedure was refereed by calculating the Student's t- and F-values. At 95\% confidence level, the calculated $\mathrm{t}-$ and F-values did not overstep the theoretical values as noticeable from Table V. Consequently, it was concluded that there is no significant difference between the proposed method and the standard method. Moreover, the spectrophotometric method for the determination of captopril in pharmaceutical tablets addressed in this work is simple, fast, inexpensive, precise, and accurate and it may be suitable for routine analysis and quality control laboratories.

In the literature, captopril was quantified using different oxidizing agents through spectrophotometric technique. Table VI views the optimization results of the determination of captopril using different reagent reactions and the proposed method. Despite that some analytical method have lower LOD value and wider linear range, but the proposed method does not need pre-extraction of the sample beside the easy and short time of the reaction.

\section{CONCLUSION}

The proposed method has the expediency of simplicity and rapidity for the determination of captopril in both bulk and dosage forms and interferences free from common tablet excipients. The investigation method comprises less rigorous control of experimental parameters such as the stability of the colored reagent dye, time of reaction, and temperature independence. The reagents applied in the proposed method are low-priced, easily accessible and the procedure does not comprise any laborious sample preparation. These preferences boosted the application of the proposed method in routine quality control of captopril in industrial laboratories.

\section{REFERENCES}

Abdel-Hady, A.M., 2013. Kinetics of oxidative degradation of rhodamine-B by $\mathrm{N}$-bromosuccinimide in aqueous alkaline medium. European Journal of Chemistry, 4(3), pp.292-296.

Ali, M.A., Moghaddasi, J., and Ahmed, S.A., 1991. Temperature effects in rhodamine $\mathrm{B}$ dyes and improvment in $\mathrm{CW}$ dye laser performance. Laser Chemistry, 11, pp.31-38.

Ana, B.F.V., Odonírio, A., Roseli, A.S.G., Giancarlo, R.S.B., and Robson, T.S.O., 2014. Electroanalytical determination of captopril in pharmaceutical formulations using boron-doped diamond electrodes. International Journal of Electrochemical Science, 9, pp.1044-1054.

Chenl, D., Chen, H., and Ku, H., 1995. Degradation rates of captopril in aqueous medium through buffer-catalysis oxidation. Drug Development and Industrial Pharmacy, 21(7), pp.781-792.

El-reis, M.A., Attia, F.A., and Kenawy, I.M.M., 2000. Indirect determination of captopril by AAS. Journal of Pharmaceutical and Biomedical Analysis, 23(2), pp.249-254.

El-Didamony, A.M., and Erfan, E.A., 2010. Utilization of oxidation reactions for the spectrophotometric determination of captopril using brominating agents. Spectrochimica Acta Part A: Molecular and Biomolecular Spectroscopy, 75(3), pp.1138-1145.

El-Shanawany, A.A., El-Adl, S.M., Abdel-Aziz, L.M., and Hassan, A.F., 2014. Spectrophotometric determination of cefradine and captopril in their bulk and dosage forms using O-phthalaldhyde (OPA). Asian Journal of Pharmacentical Analysis, 4(1), pp.36-41.

Florentin, T., Alexandru, F., Andrei, M., and Victor, D., 2004. Captopril. Encyclopedia of Endocrine Diseases, 1, pp.447-450.

Fu, Z., Huang, W., Li, G., and Hu, Y., 2017. A chemiluminescence reagent free method for the determination of captopril in medicine and urine samples by using trivalent silver. Journal of Pharmaceutical Analysis, 7(4), pp.252-257.

International Conference on Harmonisation. 2005. Topic Q2 (R1): Validation of Analytical Procedures: Text and Methodology. International Conference on Harmonisation, Switzerland.

Iqbal, F.M., Ahmad, M., Zubair, M.M., Tulain, U.R., and Rashid, A., 2015. Determination of captopril in plasma by high-performance liquid chromatography: Application in an in-vivo evaluation of drug release from hydrogel. Latin American Journal of Pharmacy, 34(5), pp.875-884.

Jia, L., Pei, R., Lin, M., and Yang, X., 2001. Acute and subacute toxicity and efficacy of S-nitrosylated captopril, an ACE inhibitor possessing nitric oxide activities. Food and Chemical Toxicology, 39(12), pp.1135-1143.

Leenson, I.A., 1999. Old rule of thumb and the arrihenius equation. Journal of Chemical Education, 76(10), pp.1459-1460.

Lewis, I.F., Hunsicker, L.G., Bain, R.P., and Rohde, R.D., 1993. The effect of angiotensin-converting enzyme inhibition on diabetic nephropathy. The New England Journal of Medicine, 329(20), pp.1456-1462.

Lima, M.J., Fernandes, R.N., Tanaka, A.A., and Reis, B.F., 2016. Development of a new procedure for the determination of captopril in pharmaceutical formulations employing chemiluminescence and a multicommuted flow analysis approach. Luminescence, 31(1), pp.288-294. 
Marcolino-Junior, L.H., Bonifacio, V.G., Vicentini, F.C., Janegitz, B.C., and Fatibello-Filho, O., 2009. Amperometric determination of captopril using a carbon paste electrode in flow analysis. Canadian Journal of Analytical Sciences and Spectroscopy, 54(1), pp.45-51.

Milan, R., Joanna, B., Anna, R., and Waldemar, M., 2015. Molecular structure and acidity of captopril, zofenopril and their metabolites captopril disulfide and zofenoprilat. Computational and Theoretical Chemistry, 1062, pp.50-55.

Moldovan, Z., Badea, I.A., Bunaciu, A.A., and Aboul-Enein, H.Y., 2012. Indirect spectrophotometric method for determination of captopril using $\mathrm{Cr}(\mathrm{VI})$ and diphenylcarbazide. Quimica Nova, 35(8), pp.1668-1672.

Parving, H.H., Andersen, A.R., Smidt, U.M., Christiansen, J.S., Oxenboll, B., and Svendsen, P.A., 1983. Diabetic nephropathy and arterial hypertension: The effect of antihypertensive treatment. Diabetes, 32(2), pp.83-87.

Pereira, C.M., and Tam, Y.K., 1992. Stability of captopril in tap water. American Journal of Hospital Pharmacy, 49(3), pp.612-615.

Phillip, M., and Hall, M.D., 2006. Prevention of progression in diabetic nephropathy. Diabetes Spectrum, 19(1), pp.18-24.

Rao, K.S., Panda, M., Keshar, N.K., and Yada, S.K., 2012. Simultaneous estimation of captopril and hydrochlorothiazide in combined dosage forms. Chronicles of Young Scientists, 3(1), pp.37-41.

Ribeiro, P.R., Pezza, L., and Pezza, H.R., 2010. A simple spectrophotometric method for the determination of captopril in pharmaceutical preparations using ammonium molybdate. Eclética Química, 35(3), pp.179-188.

Safila, N., Najma, S., and Saeed, A.M., 2013. Method for the determination of captopril in bulk, pharmaceutical formulations and serum by HPLC using two different system. American Based Research Journal, 2(3), pp.8-14.

Salem, I.I., Abu Saif, W., Jmeian, Y., and Al Tamimi, J.I., 2005. A selective and rapid method for the quantification of captopril in human plasma using liquid chromatography/selected reaction monitoring mass spectrometry. Journal of Pharmaceutical and Biomedical Analysis, 37(5), pp.1073-1080.

Shafi, N., Siddiqui, F.A., Sultana, N., and Arayne, M.S., 2015. Concurrent determination of diltiazem, lisinopril, captopril, and enalapril in dosage formulations and in human serum by liquid chromatographic technique. Journal of Liquid Chromatography and Related Technologies, 38(15). pp.1466-1473.

Skowron, M., and Ciesielski, W., 2011. Spectrophotometric determination of methimazole, D-penicillamine, captopril, and disulfiram in pure form and drug formulations. Journal of Analytical Chemistry, 66(8), pp.714-719.

Tahir, T.F., Qader, A.F., Salih, M.I., and Rashid, E.Q., 2019. L-tryptophan as fluorescent probe for determination of folic acid in some pharmaceutical products. ARO The Scientific Journal, 7(2), pp.19-26.

Tomas, P., Carmen, M., and Raquel, G., 2006. Development and validation of a capillary electrophoresis method with laser-induced fluorescence detection for the determination of captopril in human urine and pharmaceutical preparations. Electrophoresis, 27(12), pp.2310-2316.

Vancea, S., Imre, S., Donath-Nagy, G., Bela, T., Nyulas, M., Muntean, T., and Borka-Balas, R., 2009. Determination of free captopril in human plasma by liquid chromatography with mass spectrometry detection. Talanta, 79(2), pp.436-441.

Zhang, P., Wang, L., Zing, J., Tan, J., Long, Y., and Wang, Y., 2020. Colorimetric captopril assay based on oxidative etching-directed morphology control of silver nanoprisms. Microchim, 187, pp.107-115.

Zhaofu, F., Wanting, H., Gongke, L., and Yufei, H., 2017. A chemiluminescence reagent free method for the determination of captopril in medicine and urine samples by using trivalent silver. Journal of Pharmaceutical Analysis, 7(4), pp.252-257. 